\title{
Pandemic PD: Sustaining Inquiry and Community Amid K-12 Uncertainty
}

\author{
Jessica P. Marcolini', Heather Skaza Acosta2,3, Heather Walsh-Haney4, Brian Johnson ${ }^{5}$, Susan J. Cooper ${ }^{6}$, \\ and Laura Frost ${ }^{7}$

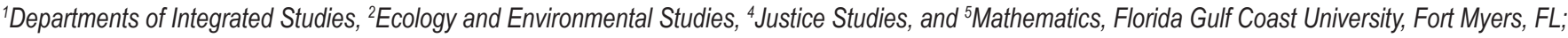 \\ ${ }^{3}$ Department of Education, Conservancy of Southwest Florida, Naples, FL; and Colleges of ${ }^{6}$ Education and ${ }^{7}$ Arts and Sciences, Florida Gulf Coast University, \\ Fort Myers, FL
}

Keywords: K-12 teacher professional development, STEM education, virtual learning, STEBI

Publication Date: August 30, 2021

DOI: https://doi.org/10.15695/jstem/v4i3.06

\begin{abstract}
We describe a long-standing weeklong K-12 STEM teacher workshop that shifted to a virtual platform in 2020. We re-engaged former participants during this STEM Institute with goals of 1) modeling ways to connect best practices for STEM education gained in previous workshops to a virtual environment, 2) providing space for teacher reflection on their virtual learning implementation during Spring 2020 without sufficient planning time, 3) offering collaborative planning time as they prepared for the Fall 2020 semester, and 4) supporting Southwest Florida STEM teachers through community building during the institute. We continued to focus our delivery (previously in person now virtually) on the $5 \mathrm{E}$ model (BSCS, 1987). Drawing upon past participant surveys and anecdotal data from previous years, facilitators addressed teachers' need for tools and lessons they could implement in their own virtual classes in the fall with plenty of time to listen and learn from each other. Here we discuss our virtual STEM Institute structure in contrast to previous years, virtual tools demonstrated by facilitators and teacher participants, and facilitator experiences and outcomes during the virtual workshop. We provide both qualitative and quantitative summary data from participant surveys on satisfaction with STEM Institute components related to the goals described.
\end{abstract}

\section{INTRODUCTION}

Despite the over 15,000 school districts in the U.S., all offering multiple professional development programs with various sponsors, the effective preparation, induction, and professional development of STEM teachers has been poorly studied (Wilson, 2011). In fact, Wilson characterizes the variety of professional learning opportunities as "carnivalesque" and the literature too varied and uneven to draw strong empirical claims. Current comprehensive reviews of STEM teacher professional development are lacking. Wilson's review "suggests that professional development in STEM, when available, is often short, fragmented, ineffective, and not designed to address the specific need of individual teachers" (National Research Council, 2011, pp. 20-21). Quality professional development activities for K-12 teachers in STEM are necessary.

The literature also tells us that there is a definite link between teacher confidence, anxiety, efficacy, and the student's ability to learn (Riggs and Enochs, 1990; Tschannen-Moran et al., 1998). There is further evidence that when teachers are uncomfortable teaching topics, they tend to avoid them or deliver superficial coverage (Brusal and Paznoka, 2006, National Research Council, 2007). At no time in history has teachers' self-efficacy been more important than during 2020 when teachers were asked to learn new technologies while shifting to remote teaching.

The forced transition to remote teaching brought on by COVID-19 did not surprise the education community with its lessons about equity in education. Students in families with high socioeconomic status (SES) have much greater access to STEM coursework and achievements from kindergarten through college than their peers in families with lower SES. High SES families and schools are better able to provide the resources, exposure, and experiences that lead to STEM success (Ma and Liu, 2017). There are specific inequities in access to technological resources. Only three percent of teachers in high-poverty schools agreed that "students have the digital tools they need to effectively complete assignments while at home," compared to $52 \%$ of teachers in more affluent schools (Darling-Hammond et al., 2014). The impacts of these inequities were pronounced as South- 
west Florida transitioned to at-home learning in the spring of 2020. Districts rushed to provide computers and internet access support to students who did not have those resources. Additionally, STEM access and achievement challenges faced by rural communities often intersect with socioeconomic access to STEM resources. In many areas across the U.S., rural communities are home to other underserved groups. Immigrant families are increasingly settling in rural communities, resulting in a growing number of traditionally marginalized students in rural schools (Schafft et al., 2006). Rural access to STEM expertise and education is low, when compared to their non-rural peers.

The Southwest Florida region including Charlotte, Collier, Lee, Glades, and Hendry counties exemplifies this overlap of rural and traditionally marginalized communities. The four largest districts within this region have free and reduced lunch rates higher than the State of Florida average of $64.1 \%$ (Florida Department of Education, 2020). While Lee and Collier districts have urban centers, Charlotte, Glades, and Hendry districts have much more rural populations. Areas within our region including Glades, Hendry, and the Immokalee area of Collier County were designated a federal, rural "Promise Zone," with a poverty rate of 31\% in 2016 (Housing and Urban Development Exchange, 2021).

The virtual 2020 STEM Institute was designed to support teachers and their students who were underserved in STEM disciplines during the pandemic when inequity in education was on the rise. While the revised institute was intended to benefit teachers as they transitioned to virtual and hybrid learning due to COVID-19, it was also designed to support teachers and their students in other ways. We hoped to leverage the forced transition by creating more equitable STEM engagement opportunities for students in Southwest Florida.

History of the STEM Institute. In 2012 The Whitaker Center for STEM Education at Florida Gulf Coast University (FGCU) and the Conservancy of Southwest Florida began planning the first STEM Institute to be held in the summer of 2013. Since then, we have offered two identical one-week STEM Institutes each summer, one in June and one in July. In 2013 the STEM Institute had two primary goals: 1) to expose teachers to outdoor and classroom technology emerging in our region, including Vernier probes and iPads, and 2) to introduce teachers to a website that houses the Florida Department of Education standards commonly referred to as CPALMS (CPALMS, 2019). As technology and tools like Vernier probes and iPads have become more mainstream, the goals of the STEM Institute shifted more toward STEM instruction in an effort to improve STEM teacher self-efficacy in classroom pedagogy and STEM content instruction. These pedagogies include backward design (Wiggins and McTighe, 1998) and lesson planning delivered in the 5E instructional model of Engage, Explore, Explain, Elaborate, and Evaluate (Bybee, 2009).

Another shift came in 2015 when The Whitaker Center for STEM Education at FGCU received a generous donation from the Richard M. Schulze Family Foundation to enhance the development of K-12 STEM teachers over the next five years. One of the areas for enhancement included in-service teachers who attend the STEM Institute. Beginning with the summer of 2016, teachers who attended the STEM Institute were compensated for their travel mileage and provided a $\$ 1,000$ classroom grant to purchase supplies for their STEM classroom. Between 2016-2019, 183 K-12 teacher participants from Southwest Florida benefited from this generosity as attendees to the STEM Institute. Each year, the STEM Institute planning committee (Institute facilitators and authors of this paper) meet to discuss and modify the STEM Institute for the next year through an evaluation of the previous year's formative assessment and end of workshop survey. While a full discussion of the evolution of the STEM Institute is outside of the scope of this paper, we provide an outline of how the STEM Institute has shifted over the years in Table 1.

Transitioning to a Virtual Platform. The impacts of COVID-19 on school districts have been catastrophic. The STEM Institute's approach has always been to support teachers with tools and resources that can have the greatest positive impact on students, and in the wake of the pandemic it was our aim to continue that support. In order to best support teachers under unique circumstances, we instituted three major changes to the 2020 STEM Institute format.

Table 1. STEM Institute History Outline.

\begin{tabular}{ll}
\hline 2013 & 2019 \\
\hline Focus on proficiency with Technology & Focus on proficiency with 5E model
\end{tabular}
Tools

Incorporate writing and journaling in STEM through the National Writing Project

Model guided inquiry lessons based on CPALMS lesson plans

Model guided inquiry lessons based on the $5 \mathrm{E}$ model

All sessions included all grade levels

Some sessions are conducted by grade band

STEM lessons include forensics, water quality, solar energy, wildlife corridors and the environment, introduction to engineering

Interactive sessions on How People Learn, Backward Design, and Standards

Friday presentations/demonstrations from individuals to all participants to discuss their lesson plan ideas.

Deliverable: A guided inquiry lesson plan submitted to CPALMS repository (due Jan.)

STEM lessons include forensics, population dynamics and invasive species (sample: python), mangroves and tree-counting wet walk, solar energy, coding and robotics

Interactive sessions on How People Learn, Backward Design and Standards

Friday roundtables in grade bands to discuss lesson plan ideas.

Deliverable: A 5E lesson plan submitted to the STEM Institute suitable for the FGCU repository (due Jan.) 
The Institute

- was presented virtually;

- focused on supporting teachers' best practices in virtual and hybrid student-centered teaching;

- $\quad$ provided ample time for peer-to-peer mentorship and community building by having participants share lessons they implemented virtually the previous spring, discuss their expectations for the coming year, and pose questions to the group.

While the lessons about inequities in our educational system were not a surprise, the 2020 STEM Institute leveraged early COVID-19 lessons-learned to support teachers with high populations of students underserved in STEM disciplines with programming that 1) grows access to tools, technology, and expertise in STEM, 2) allows for student participation at home, and 3) maintains a long-term connection to the STEM Institute.

Through the weeklong program and continued engagement with The Whitaker Center for STEM Education at FGCU, participants create a community of practice around student-centered learning, even in a virtual or hybrid environment. The aim of the program necessarily shifted to repair the educational inequality caused by the COVID-19 crisis by creating a network of continued engagement and resource support. This paper describes the STEM Institute's transition to virtual professional development, two lesson examples, and the tools used to create and maintain a community of learners while we were unable to be face-to-face. We will also present preliminary findings from participant surveys assessing teacher self-efficacy, their perceptions of the role of scientific investigation in school, and their perceptions of the Institute and how it will inform their STEM classroom practice in the coming year.

\section{METHODS}

In the following sections we describe the STEM Institute's historical program structure, and how it was transformed for the summer of 2020. Table 2 outlines the main changes.

Table 2. Summary of STEM Institute's Transition to Virtual.

\begin{tabular}{ll}
\hline \multicolumn{1}{c}{$\begin{array}{c}\text { Previous STEM Institutes } \\
(\mathbf{2 0 1 3 - 2 0 1 9 )}\end{array}$} & \multicolumn{1}{c}{$\mathbf{2 0 2 0}$ Virtual STEM Institute } \\
\hline Integrated Field Experiences & Virtual "Exploration" \\
Low-tech, minimal online presence & $\begin{array}{l}\text { Leveraged Google Classroom, Google } \\
\text { Sites, Jamboard }\end{array}$ \\
Discouraged repeat participants & $\begin{array}{l}\text { All participants were returning } \\
\text { teachers }\end{array}$ \\
Focused on 5E Model for Inquiry & $\begin{array}{l}\text { Focused on 5E Model for Inquiry } \\
\text { Instruction (Bybee) }\end{array}$ \\
Instruction (Bybee) & 21 Participants, 1 session \\
\hline 50 Participants, 2 sessions &
\end{tabular}

Participants. Historically, STEM Institute facilitators recruited teacher participants through an open application and review process, prioritizing four participant qualifications: employment with a Title 1 school, distribution of participants among elementary and secondary grade bands, representation across FGCU's five-county service region, and having no previous participation in the Institute. In the first years of the Institute an average of 30 participants were accepted each summer. Since 2016, two cohorts of 25 participants have been accepted each summer.

Since the 2020 Institute would be drastically different from previous years in regard to content and format, facilitators decided that repeated participation was desired so that participants were familiar with the general characteristics of the Institute, including the emphasis on guided inquiry learning using the 5E model and teacher self-efficacy. In 2020, facilitators recruited former participants who had demonstrated their understanding of the Institute's characteristics and/or continued to be leaders in their schools directly. One cohort of 21 was accepted and participated in July of 2020. Participants represented four SW Florida counties, with nine elementary teachers, eleven secondary teachers, and one former middle school teacher who transitioned to a district curriculum specialist. While all participants were STEM Institute alumni, the 2020 STEM Institute was a completely different professional development program, so all content was new to participants.

Program Structure. The daily schedule for the 2020 STEM Institute is shown in Table 3. Each day included four activities:

1. Lesson introduction, focusing on one of the $5 \mathrm{E}$ phases each day;

2. Independent work time for participants to engage with a virtual guided inquiry $5 \mathrm{E}$ lesson;

3. Collaborative presentation by grade band and reflection on lessons completed during Spring 2020 remote teaching;

4. Open discussion time to reflect on challenges and successes of Spring 2020.

The re-engagement of past STEM Institute participants and the pivot to a virtual setting in 2020 modified the STEM Institute's goals from previous years. Since participants were experienced in guided inquiry teaching pedagogies including the 5E model, the primary program goal during the 2020 STEM Summer Institute was increasing teachers' ability and confidence in student-centered virtual learning by focusing on effective 5E strategies for remote teaching. We also wanted to give the participants some time to process what they had experienced as the pandemic unfolded and then to think about how they would manage their return to school in Au- 
Table 3. Overview of 2020 Institute Schedule.

\begin{tabular}{|c|c|c|c|c|c|}
\hline & Monday & Tuesday & Wednesday & Thursday & Friday \\
\hline 9:00 AM & Introductions & Debrief & Debrief & Debrief & Debrief \\
\hline 9:30-10:30AM & Engage: Coding & Explore: Chemicals & Explain: Pythons & Extend: Beetles & Evaluate: Writing \\
\hline $\begin{array}{l}\text { 10:30-11:30AM } \\
\text { Facilitators available }\end{array}$ & Independent Work & Independent Work & Independent Work & Independent Work & Closing Remarks \\
\hline \multicolumn{6}{|l|}{ Lunch Break } \\
\hline $\begin{array}{l}\text { 12:30PM } \\
\text { Facilitators available }\end{array}$ & $\begin{array}{l}\text { Breakout I: K-2 Teacher } \\
\text { Lessons }\end{array}$ & $\begin{array}{l}\text { Breakout I: 3-5 Teacher } \\
\text { Lessons }\end{array}$ & $\begin{array}{l}\text { Breakout I: 6-8 Teacher } \\
\text { Lessons }\end{array}$ & $\begin{array}{l}\text { Breakout I: 9-12 Teacher } \\
\text { Lessons }\end{array}$ & $\begin{array}{l}\text { Reflection and Institute } \\
\text { Evaluation }\end{array}$ \\
\hline 1:00-1:25PM & Debrief Lessons & Debrief Lessons & Debrief Lessons & Debrief Lessons & \\
\hline \multicolumn{6}{|l|}{ Break } \\
\hline 1:35-2:00PM & Breakout II & Breakout II & Breakout II & Breakout II & \\
\hline 2:05-2:30PM & Debrief Breakout II & Debrief Breakout II & Debrief Breakout II & Debrief Breakout II & \\
\hline
\end{tabular}

gust. Beauchamp et al. (2014) found that professional learning opportunities that prioritized conversations and collaborations through the allocation of time for teachers to meet and talk fostered higher self-efficacy and collective efficacy among participants. Based on our sense that participants needed this less structured time to build community, we prioritized small group discussions and time for reflection at the end of the daily programming. This idea is supported by Krim et al. (2019), who identified networking and communication among peers participating in the same professional learning experience as a key reinforcement of instructional change.

Offering collaborative planning time to aid in preparation for the Fall 2020 semester and supporting participants through community building during the STEM Institute was accomplished through two afternoon breakout sessions (I and II) Monday-Thursday. Prior to the start of the Institute, we asked teachers if they would be willing to share a lesson from the past year with other participants in their grade band. The facilitators identified four participants (one per day) that would model a lesson for peers during Breakout session I. This session was optional for participants in other grade bands. In Breakout II, we asked the participants to think about their classrooms, their needs, their students' needs, and their resources with one of the facilitators. The Breakout II discussion prompts were as follows:

- Monday: Contrast your classroom face-to-face with virtual - what was different, what stayed the same?

- Tuesday: How did you manage your students? Were your courses synchronous or asynchronous? Were they mostly present/absent? Were parents more or less engaged? (I want to hear some stories, good and not so good)

- Wednesday: What do you want to do to support your students and families in the Fall?

- Thursday: What new resources might you use this Fall? Other topics about Fall teaching and what you are planning are also encouraged.
While facilitators were available throughout the day via Zoom, participants were only required to attend the lesson demonstrations from 9:30-10:30, lesson debriefs from 1:00$1: 25$, and Breakout session II and debrief from 1:35-2:30. This structure required participants be logged into Zoom with cameras on for 2 to 3 hours per day. Participant engagement in the remaining 2.5 to 3.5 hours was optional.

Virtual Tools. While not demonstrated as an educational tool, the Institute's main communication platform was Zoom. Additionally, the week's activities were all housed in a Google Classroom that all teacher participants were invited to join. Participants were familiar with Google Classroom as it was used in the local school districts pre-pandemic and is still used now. Three virtual tools that were used to engage participants and were presented as tools to improve their classroom practice were Google Sites, Google Jamboard, and Concord Consortium's SageModeler. Each STEM Institute lesson included the modeling of one or more of these tools with the hope that teacher participants would find them useful and adapt them according to their classroom needs in the coming school year.

Daily tasks and content were presented in Google Sites, a structured web page-creation tool that made it possible to create on-line lessons that were as interactive virtually as in-person field-based lessons. Each Google Site was a multipage website, with each of the 5Es on its own webpage, along with a linked Google Doc for participants to use as a science journal as they completed each lesson or activity (Figure 1). Google Site web-based tools were chosen for their intuitive format. Participants could learn the software with ease, if they chose to use it with their students in the fall. Additionally, most school districts in the region were connected to the Google Suite of tools, so Google Sites could integrate tools with which they were already familiar.

Google Jamboard is a digital and interactive whiteboard that can be used to collaboratively add ideas to a common workspace. We chose this tool for its integration with other 


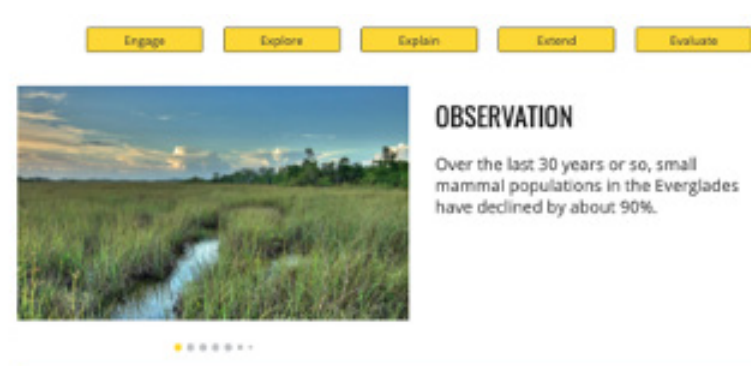

PHENOMENON AND ANCHORING QUESTION

NATVE ANIMAL populations are dramatically declining in the Everglades. What is causing the decrease in native wildite populations in the Everglades ecosystem and what can we do abous in

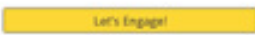

NEXT GENERATION SUNSHINE STATE STANDARDS

\section{TEACHER'S GUIDE}

Figure 1. 2020 virtual STEM Institute Google Site template organized using the $5 \mathrm{E}$ model.

Google tools and because it supported explicit thinking and collaborative learning as participants reviewed each other's ideas. A common use of Jamboard during the Institute was to create a space for idea sharing in the Explain section of the $5 \mathrm{E}$ model. We used Jamboard in a way that participants could share their ideas both in writing and through digital media. Teaching tools that allow individuals to utilize visual supports such as pictures, videos, and graphics have been found to benefit English Language Learners with complex science vocabulary and concepts (Silverman and Hines, 2009).

Finally, Concord Consortium's SageModeler is a webbased systems thinking and modeling tool. This tool was used in the Explore and Explain sections of the 5E model for the Python Problems population dynamics lesson. SageModeler allows participants to represent their understanding of complex systems, change variables in each system, and simulate the outcomes of their decisions. This tool was presented as particularly helpful for scaffolding individuals' understanding of complex systems and supporting emerging bilingual students in the practices of STEM, without textheavy descriptions.

Additionally, during Breakout session I, the participants who chose to attend and share lessons demonstrated other teaching tools and resources such as NearPod and FlipGrid.

The following lessons from the virtual STEM Institute illustrate how previous field-based lessons were translated to a virtual platform, while maintaining inquiry-based practice, utilizing one or more of the virtual tools described.

Lesson Transformation: Skeletons and Soils. This activity introduces teachers to forensic science as a way to apply principles of science, math, and geology to real-world problems by discovering and excavating possible skeletal remains while recognizing that the environment directly impacts these processes. In previous years, we presented two, two-hour modules.

We brought the forensic experience to the participants differently in 2020 through an activity that examined variations in insect abundance using Hide beetles (Dermestes maculatus, Figure 2). Lesson materials were shared with participants through Google Sites within the Google Classroom. As participants moved through the 5Es in Google Sites during the morning presentation, they developed research ideas that would further their understanding of Dermestes maculatus behavior and categorized their research ideas as either natural or controlled experiments. Participants learned that the lesson could be adapted to a variety of grade levels to include science standards aligning with population density, the physical and chemical weathering of the earth's soils, soil stratigraphy, and the interaction of biological organisms throughout life.

The forensic lesson culminated in small group Zoom discussions with teacher participants brainstorming ways they could implement a similar virtual, yet hands-on, 5E project in their own classrooms. Earlier in the summer, the forensics facilitation team led virtual lessons paired with the distribution of "beetle hotel" kits to middle school campers. The team used this experience to promote discussions among STEM Institute participants on how they could utilize handson materials to engage students virtually. Table 4 provides an overview of how each of the $5 \mathrm{E}$ phases of the lesson were adapted from an in-person to virtual format while combining participant engagement and learning outcomes.

\section{Lesson Transformation: Python Population Dynamics.} This activity presented the story and research on one of Southwest Florida's most impactful invasive species, the Burmese python. The activity engages learners with

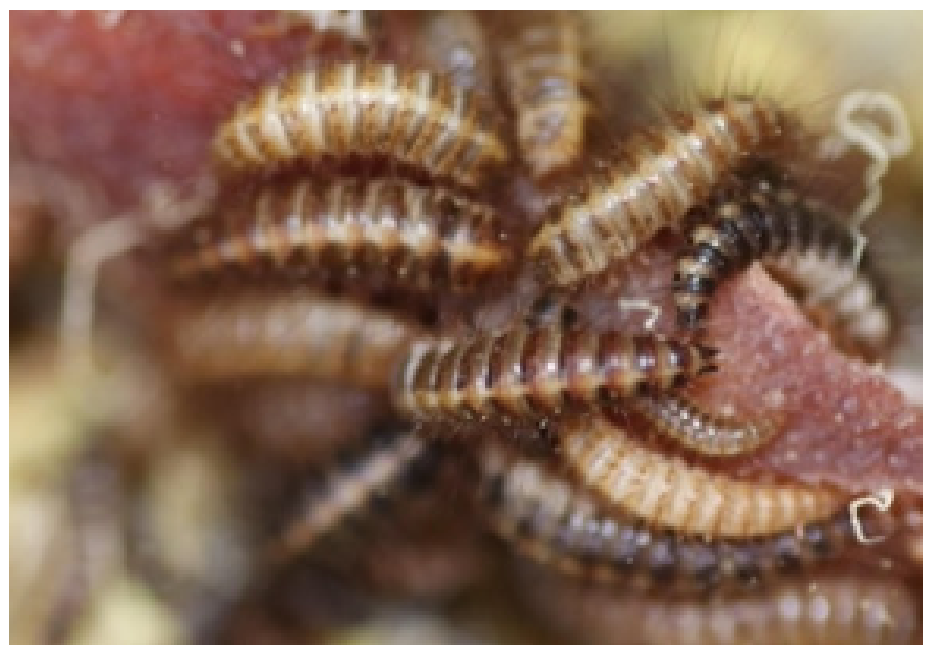

Figure 2. The Hide Beetles (D. maculatus), which were the subject of the virtual 5E forensic lesson. Photo credit: Amy Pham. 
Table 4. Review of How Skeletons and Soils 5E Model Elements Changed Based on Teaching Modality.

\begin{tabular}{|c|c|c|}
\hline 5E Element & In-person Activity & Virtual Activity \\
\hline Engage & $\begin{array}{l}\text { Group discussions: How } \\
\text { do scientists locate buried } \\
\text { bodies and estimate how } \\
\text { long the remains have been } \\
\text { dead? }\end{array}$ & $\begin{array}{l}\text { Short videos on Galapagos } \\
\text { finch studies with individual } \\
\text { reflection and Google Form } \\
\text { submission. }\end{array}$ \\
\hline Explore & $\begin{array}{l}\text { Group work: Work through } \\
\text { field stations to locate } \\
\text { subsurface changes, record } \\
\text { soil color, use soil probes, } \\
\text { and map burial. }\end{array}$ & $\begin{array}{l}\text { Virtual module on Gregor } \\
\text { Mendel and inheritance. }\end{array}$ \\
\hline Explain & $\begin{array}{l}\text { Group work: Groups } \\
\text { answer critical thinking } \\
\text { questions with facilitator as } \\
\text { part of the module. }\end{array}$ & $\begin{array}{l}\text { Small group breakout } \\
\text { discussions about natural } \\
\text { vs. controlled experiments } \\
\text { and how these would be } \\
\text { conducted in virtual, face-to- } \\
\text { face, or hybrid environments. }\end{array}$ \\
\hline Elaborate & $\begin{array}{l}\text { Famous and current } \\
\text { forensic case stories are } \\
\text { presented to participants by } \\
\text { the facilitator. }\end{array}$ & $\begin{array}{l}\text { Virtual module about } \\
\text { Dermestes maculatus } \\
\text { beetles and their role in } \\
\text { decomposition. }\end{array}$ \\
\hline Evaluate & $\begin{array}{l}\text { Group work: Participants } \\
\text { present how they would } \\
\text { bring versions of the topics } \\
\text { into their own classrooms. }\end{array}$ & $\begin{array}{l}\text { Design an experiment } \\
\text { in which students would } \\
\text { use } D . \text { maculatus beetles } \\
\text { to infer relevant forensic } \\
\text { information. }\end{array}$ \\
\hline
\end{tabular}

the concepts of population dynamics and organismal relationships. In addition, learners use and create models as a scientific practice to make their understanding of systemic ecosystem interactions explicit (Lehrer and Schauble, 2006). From 2017 to 2019, this activity was presented in-person during a two-hour session at the Conservancy of Southwest Florida, where participants interacted with the organization's python research biologists during a python necropsy. During the summer of 2020, the activity was converted to a Google Sites virtual lesson (Figure 3). STEM Institute participants interacted with the python biologists virtually and via video recording. Participants were also introduced to Concord Consortium's virtual tool, SageModeler. They used the online modeling tools to create simulated population models of native species and the invasive Burmese python. The session concluded with a gallery walk where groups shared their simulations and revised their own models based on peer feedback. Table 5 briefly describes how learners engaged with each of the 5Es in the in-person and virtual environments to highlight the changes that were made, but with the hope of achieving the same learning outcomes.

Assessments. Teacher participants were surveyed to investigate three variables: their perceptions of the Institute and its usefulness to their classroom practice, their self-efficacy in teaching STEM disciplines, and their implementation of science investigations in their classrooms.

Teacher Participants' Perceptions of The STEM Institute. During the 2020 STEM Institute, participants were surveyed

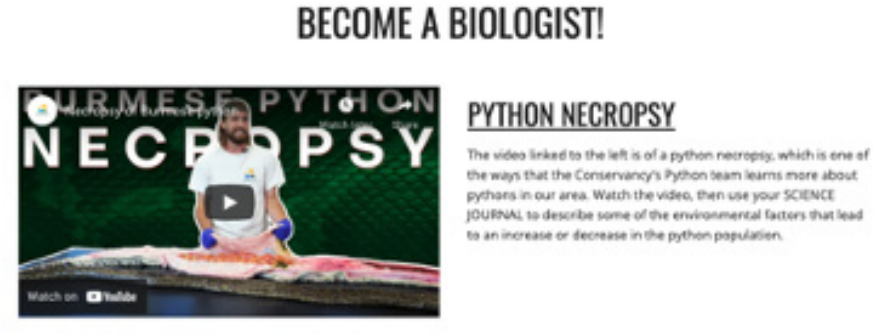

\section{JOIN THE TEAM!}

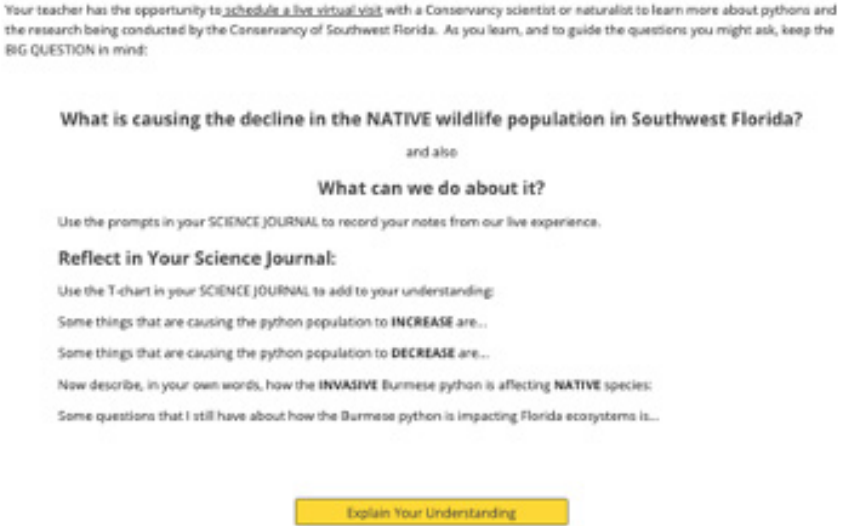

Figure 3. 2020 virtual STEM Institute Python Population Dynamics Google Sites "Explore" Activity.

daily at the conclusion of each day's activities. Surveys from Monday through Thursday were nearly identical, broken into three short pieces about the morning session, the afternoon session, and the day overall. Participants rated their agreement on six statements about the morning session on a five-point Likert scale: (a) This time was well spent, (b) I was intellectually engaged with the ideas presented, (c) I increased my knowledge/understanding of the content presented, (d) The presenter was highly qualified in the field, (e) The materials provided will be useful in my classroom, and (f) I can use the materials provided with modifications. For the afternoon session, there was a single free response question pertaining to the Breakout II discussion (referred to as 4th Q because remote teaching mostly coincided with the 4th quarter of the school year): "What is something from the 4th Q breakout session that will be useful as you look toward and prepare for the coming academic year?" Finally, participants were given the opportunity to provide free responses to three prompts about the day's activities overall: (i) The most important thing you learned (or liked about) today, (ii) One "Aha!" moment you had today, and (iii) Suggestions for tomorrow or things from today that remain unclear.

Friday's survey focused primarily on the workshop as a whole. In addition to reusing (a), (e), and (f) from the Likert scale statements above, participants were also asked their level of agreement about the length of the workshop (one week) and the amount of active screen time versus the 
Table 5. Review of How Python Population Dynamics 5E Model Elements Changed Based on Teaching Modality.

\begin{tabular}{|c|c|c|}
\hline 5E Element & In-person Activity & Virtual Activity \\
\hline Engage & $\begin{array}{l}\text { Table partner discussion: } \\
\text { What do you already } \\
\text { know about pythons in } \\
\text { Southwest Florida? }\end{array}$ & $\begin{array}{l}\text { Science Journal reflection: } \\
\text { How are organisms related in a } \\
\text { healthy ecosystem? }\end{array}$ \\
\hline Explore & $\begin{array}{l}\text { Python necropsy in } \\
\text { lab, article reading, and } \\
\text { reflection in groups }\end{array}$ & $\begin{array}{l}\text { Virtual modules on invasive/ } \\
\text { native/exotic species, } \\
\text { population dynamics; video } \\
\text { recorded necropsy, live, virtual } \\
\text { Q and A with the Conservancy } \\
\text { python biologists }\end{array}$ \\
\hline Explain & $\begin{array}{l}\text { Create progressively } \\
\text { more complex models of } \\
\text { Everglades ecosystem, } \\
\text { simulated and physical, } \\
\text { depending on grade band. }\end{array}$ & $\begin{array}{l}\text { Build simulated models } \\
\text { of Everglades ecosystem, } \\
\text { using Concord Consortium's } \\
\text { SageModeler and test policy } \\
\text { decisions to measure impact of } \\
\text { actions. }\end{array}$ \\
\hline Elaborate & $\begin{array}{l}\text { Time limitations } \\
\text { prevented completing this } \\
\text { element. }\end{array}$ & $\begin{array}{l}\text { Use SageModeler to create } \\
\text { simulated model for novel } \\
\text { invasive species. }\end{array}$ \\
\hline Evaluate & $\begin{array}{l}\text { Gallery walk to view } \\
\text { peer models and revise } \\
\text { own model based on peer } \\
\text { learning. }\end{array}$ & $\begin{array}{l}\text { Virtual gallery walk, using } \\
\text { Google Jamboard, providing } \\
\text { praise, critique, and question to } \\
\text { peers. Revise own model based } \\
\text { on peer learning. }\end{array}$ \\
\hline
\end{tabular}

amount of individual time in the daily schedule. Participants were invited to choose from the week's activities which they found most useful and which they found least useful, and they were given the option to add topics they would have liked to explore. Finally, as part of the Friday survey, participants were given five reflective response questions:

- In the pre-survey, we asked you to tell us what you hoped to gain this week. Did you get what you were hoping from the workshop?

- In what ways has your STEM teaching efficacy been impacted based on attending the 2020 virtual STEM Institute?

- In what ways has your STEM teaching efficacy in a virtual environment been impacted based on attending the 2020 virtual STEM Institute?

- What were the top three beneficial parts of this workshop for you (do not have to be actual sessions)? Explain.

- What was the least beneficial part of this workshop for you (again, does not have to be a session)? Explain.

Self-efficacy in Teaching STEM Disciplines. In previous years we collected quantitative surveys both before and after the Institute. Due to the upheaval caused by the pandemic in Spring 2020 we failed to administer any quantitative pre-survey. However, 2020 participants were asked to complete the Science Teaching Efficacy Belief Instrument (STEBI) the week following the Institute. The STEBI provides a concise and adaptable tool made up of 25 forward and reversed phrased items used to measure participants' beliefs of their efficacy for teaching (Riggs, 1988). In an attempt to have the STEBI questions focus more specifically on STEM subjects, we utilized a modified version that replaced any reference of the term science with STEM (Bleicher, 2004; Nadelson et al., 2012). The modified in-service STEM version of the STEBI achieved a satisfactory level of instrument reliability with an $\alpha$ of .85 and has been utilized in other subsequent research to assess teachers' self-efficacy in STEM instruction (Cooper et al., 2014; Nadelson et al., 2012).

\section{Implementation of Science Investigation in The Classroom.} As with the STEBI, 2020 STEM Institute participants were asked to complete the Inquiry Science Implementation Scale (ISIS) as a post-survey that was administered directly after the Institute. The ISIS aided in the examination of the implementation of science investigations in three phases: introduction, preparation and conduction, and summary (Brandon et al., 2009). As a self-reporting instrument, ISIS requires teacher participants to respond to 22 items based on the statement, "When you teach science, how frequently do you". Internal consistency and test-retest analyses reported satisfactory reliability of the instrument; the two administrations of the questionnaire achieved a coefficient $\alpha$ of 0.87 and 0.89 (Brandon et al., 2009).

\section{Next-year Follow-up.}

Lesson Plans. One of the key features of the STEM Institute is a classroom grant that participants receive for participation in the STEM Institute. One of the deliverables that we ask of the participants is a lesson plan for a STEM activity based on the $5 \mathrm{E}$ model. We encourage participants to work together on these and develop their lesson ideas during the Institute. They receive peer and facilitator feedback on their ideas the last day of the workshop. Participants receive a template for the 5E lesson plan during the Institute and are asked to provide a completed lesson plan including any teaching materials by January of the following year to the facilitators for review. Two facilitators review each lesson plan and feedback is returned to the teachers with the option to revise and have their lesson posted on FGCU's repository (Florida Gulf Coast University Digital Repository, 2021).

Conference Attendance. STEM Institute participants are also invited to attend the Florida Association of Science Teacher's annual conference in October of the following year. The conference offers pre-conference workshops (often free or minimal charge) where teachers can participate in field experiences along with STEM conference sessions for K-12 teachers. Registration and hotel nights are paid for STEM Institute participants through the Schulze Foundation sponsorship. 


\section{RESULTS}

\section{Assessments.}

Teacher Participants'Perceptions of The STEM Institute. As a program assessment, preliminary examination of the daily feedback surveys from Monday through Friday indicated that we achieved our goals of providing tools that participants could use to engage students in the $5 \mathrm{E}$ instructional model in a virtual environment and building community among the participants. In response to the daily feedback surveys, all participants expressed overall satisfaction with the virtual format of the STEM Institute. When planning the curriculum and content for the Institute, it was important that we avoided "Zoom fatigue" or over-filling their daily schedule. Upon reviewing participant survey responses, all participants expressed high satisfaction with the one-week workshop length as well as the amount of active screen time versus individual time. A long-time goal of the Institute is for the participants to be able to utilize and adapt the resources provided. Even though we had teacher participants from early elementary through high school, all participants expressed agreement when asked if the materials provided would be useful in their classrooms and if they could use the materials with modifications.

Initial themes that have emerged from participants' short answer responses describing the elements of the STEM Institute that were most beneficial include the importance of community, the value of learning new virtual tools and resources, and review and demonstration of the 5E model. One participant wrote, "Seeing the 5E lessons modeled in several ways has helped me see how to adapt it to my students." This response suggests that participants are gaining the ability to utilize ideas and lessons from the Institute and adapt them to their own classrooms. Another participant highlighted the benefits of the Institute by responding, "First, Google Sites is going to be a game changer in providing lessons in the google classroom for my primary kiddos. Second, the breakout sessions were great because they gave us an opportunity to share and learn from others. Finally, the opportunity to interact with the lessons and then discuss them was beneficial in helping me process how I might use them or some face of them." This participant's response emphasizes the benefits of community building and learning of new virtual tools and resources.

Self-efficacy in Teaching STEM Disciplines. In the preliminary analysis of participants' post-STEM Institute 5-point scale surveys, participants averaged a 4.06 on the combined 25 STEBI statements, indicating a high level of self-efficacy. This average was slightly above the average post-STEBI scores from previous Institutes $(2014=4.02,2015=3.87$, $2016=4.02,2017=3.89,2018=3.91,2019=4.04)$ and could be due in part to the purposive selection process of 2020 participants from STEM Institute alumni. Due to the STE-
BI only being administered as a post-Institute survey, we do not have any quantitative data available to determine the influence of the 2020 STEM Institute on participants' teacher self-efficacy in STEM. However, qualitative responses such as, "My efficacy has exponentially increased. I am more confident in myself to use the 5E lesson plans for my students" support the notion that we achieved our goal of increasing participants' teacher self-efficacy in STEM.

Implementation of Science Investigation in The Classroom. The ISIS surveys were also only administered as post Institute surveys. However, when compared to post-ISIS average scores from previous Institutes, 2020 participants' average score of 4.32 was similar $(2013=4.45,2014=4.30$, $2015=4.11,2016=4.31,2017=4.41,2018=4.18,2019=4.27)$. Teacher participants' encouraging qualitative responses pertaining to the implementation of STEM content reinforce the above average ISIS scores of 2020 participants. For example, one participant wrote, "This virtual STEM institute was an eye opener of what I would like my science program to be more like, and guides me to integrate a balance of engaging and exemplary lessons for my students". These results provide some evidence of our effectiveness in modeling guided inquiry 5E lessons throughout the 2020 virtual STEM Institute.

\section{Next year Follow-up.}

Lesson Plans. While the facilitators diligently reviewed the lesson plans after the 2016, 2017, and 2018 STEM Institutes, the pandemic derailed the review of lesson plans in spring of 2020 and 2021. While most teachers follow through with providing us an initial lesson plan, their ability to follow through and revise those for our repository has been limited. To date we have $14 \mathrm{~K}-12$ lesson plans available in the FGCU repository. For example, in 2018, we received 30 lesson plans for review and only three of these lesson plans were revised and shared through the FGCU repository.

Conference Attendance. Many of the participants take advantage of the Florida Association of Science Teacher's (FAST) annual conference offer. In 2018, forty-three teachers attended with three facilitators and in 2019, thirty-two teachers attended with five facilitators. In 2020, the FAST conference moved to a virtual format and only nine STEM Institute participants and one facilitator attended. The FAST conference will be returning to an in-person format in 2021 and we hope to revive this activity as it has become an important community building activity for the teachers.

\section{DISCUSSION}

Virtual Teaching for Today's K-12 Teacher. For various reasons, including lack of preparation and a perceived need 
for special equipment and supplies, elementary teachers have been reticent to include meaningful science lessons in their instruction for many years (Conderman and Woods, 2008). The problem worsened when preparation for high-stakes mathematics and English language arts tests took more time out of the school day beginning in the early 2000s, causing many schools to drastically reduce the amount of time for science instruction. Since 2013, one of the goals of the Institute has been to share best practices and resources for integrating STEM lessons into the curriculum. Many of the lessons presented in all Institutes by the facilitators integrate STEM with English language arts, especially writing in the curriculum, as well as other subjects, including social studies and art. This was also true in the 2020 Institute.

The challenge of acclimating to new modalities of teaching was felt by teachers and facilitators alike. As we drafted the new virtual curriculum for the 2020 Institute, we made sure to include two key characteristics of effective teacher professional development: interactive learning opportunities and applicable models for delivering content (Darling-Hammond et al., 2017; Matherson and Windle, 2017). Our decision to model virtual tools that participants could easily adapt to their subject and grade level stemmed from Matherson and Windle's (2017) findings that teachers desire professional development opportunities that aid in the preparation and delivery of techniques and strategies that can be utilized immediately in their classrooms. As classrooms worldwide transitioned to online environments, virtual tools became the new whiteboards and PowerPoints. Virtual tools such as Google Sites and Google Jamboard allowed us to engage teacher participants in the content while also demonstrating the 5E Model. For teachers, the switch from pre-pandemic hands-on, minds-on STEM lessons to virtual STEM lessons made the inclusion of STEM in the regular school day even more challenging. Some of the most popular activities at the previous STEM Institutes included materials that most students do not have at home, such as robots and measuring tools. Further, many K-12 students do not have even minimal resources at home for STEM exploration activities, such as plastic cups, paper clips, and scissors. When classrooms went virtual, students found themselves without classmates to collaborate with on STEM projects. Further, adult supervision became problematic because the adults in many families had to continue working in person away from home. Including time in the 2020 Institute to discuss these challenges through sharing successes and failures was very important to both the K-12 participants and facilitators.

Moving to a virtual setting also challenged some of the facilitators to adapt their face-to-face lessons. For example, the in-person forensic activity focused on burial site geology, soil $\mathrm{pH}$, and temperature effects on decomposition transitioned to focus on dermestid beetle decomposition. Practice and training modeled by our STEM Institute education facil- itators aided other facilitators in planning classroom activities outlined in the examples previously mentioned.

Facilitator Reflections and Other Lessons Learned. The Institute was specifically structured to provide teacher participant support through building community with each other, the FGCU facilitators, and community partners like the Conservancy of Southwest Florida. In the following sections, we reflect on those plans and how they functioned to grow a community of STEM-confident teachers.

Building Community Through Program Structure. The daily virtual breakout sessions provided the Institute with recurring sessions and follow-up, which Darling-Hammond et al. (2009) label as a requirement of good professional development. Long term, sustained efforts allow community building to be a part of the professional development process (Eib and Miller, 2006; Crawford et al., 2021). Each participant had attended at least one STEM Institute previously and many had attended FAST conference follow-up events. Through the afternoon breakout discussion sessions that incorporated smaller groups and open discussion, the facilitators (one per breakout room) and the participants began to build a more meaningful and longer lasting community. During these sessions we were emphasized the participant's societal importance as educators. As facilitators, we believe teachers are the heart and soul of our educational system and their value is often under-appreciated and under-estimated.

\section{Community Partnerships to Support Students and Educa-} tors. While not formalized, the partnership practice that is the foundation for the STEM Institute works toward building a community of practice focused on the domain of student-led and field-based teaching and learning (Wenger, 2010). Since the Institute took place relatively early in the pandemic and prior to the beginning of the school year, partners like the Conservancy of Southwest Florida were also planning for a shift to virtual learning. Community partners contribute to and draw from community resources, like curriculum resources, partnered field experiences, and funding resources for classroom supplies. We believe the transition to a virtual environment only strengthened these partnerships, leading to sustained interaction throughout the 2020-2021 school year.

Program Planning. The logistics of doing nearly all things virtually changed immensely since the start of the pandemic, and planning the Institute was no different. Particularly challenging was developing the curriculum and daily schedule. Prior institutes from 2013-19 always included changes based on feedback and experience, but 2020 required developing a completely new program. Avoiding "Zoom fatigue" or over-filling the daily schedule forced 
difficult choices in the rest of the schedule. Some planning tasks were more of a trade-off: rather than finding available meeting spaces and field sites, we had to choose the platform for the lessons and video conferencing software. While a number of things proved more difficult, there were certainly exceptions. For example, some of the administration time and cost was reduced because there was no need to reimburse travel or purchase food. Also, discussion sessions (in virtual breakout rooms) facilitated by recording on a live Google doc provided an easily accessible record that still exists today.

Other Lessons Learned. One important lesson learned in planning and implementing a virtual K-12 STEM workshop was deciding what to scale back by teasing apart material necessary for student learning from material that we were emotionally tied to (but that does not help the participant learn the material within the activity). For example, mock burials may be difficult for teachers to accomplish in locations that prohibit digging or lack access to appropriate outdoor space for excavation while developing a kit with hide beetles can be used in a classroom or sent home with students allowing more classrooms to engage with a forensic activity. The forced transition to a virtual setting brought on by COVID-19 challenged us to better understand the hurdles our participants and their students encounter regardless of the instructional modality.

Moving Forward. While the transition to a virtual platform was unexpected, the format presented an alternative that can expand access and reduce the resources needed for meaningful teacher professional development in STEM. The STEM Institute facilitators also developed expertise in virtual teaching and learning. Moving forward, our aim is to leverage the affordance of the virtual, face-to-face, and field environments to support teachers' STEM efficacy and confidence and expand access to teachers and students in communities underserved in STEM.

The hybrid teaching and learning model adopted for the 2021 STEM Institute integrates both field experiences and virtual learning into the $5 \mathrm{E}$ model. We made choices based on which learning environment provides the most appropriate tools for the activities taking place in each "E." For example, field experiences support students' Exploration, providing environments for data collection, investigation, and observation. Virtual tools like Google Jamboard or SageModeler for concept modeling support students creating and sharing their understanding in the Explain section.

While STEM Education integrates science, technology, engineering, and mathematics into practical and applicable educational experiences (Vasquez et al., 2013), inequities have been allowed to persist in both STEM education and the workforce in regard to minority groups (Funk and Parker,
2018; National Science Board, 2016; National Academies of Sciences, Engineering, and Medicine, 2018). Changing demographics in American schools have been widely reported (Batt, 2008; Bodur, 2012; Edwards, 2011; Flores and Smith, 2008; Gay, 2010; Nasser and Overberg, 2012; Nutta et al., 2012; Ukopokodu, 2011). Student populations are becoming increasingly racially, ethnically, culturally, and linguistically diverse. Teachers must be prepared to work within diverse learning environments.

We cannot simply return to pre-pandemic professional development models for K-12 teachers in STEM, now that the pandemic assured that laptops and internet access were more equitably distributed. The updated hybrid model adopted for 2021 increases inclusion in that it supports individualized learning. Virtual modules allow students to move at their own pace and cognitive ability. When models replace text-heavy explanations and first-language support is offered, many of these virtual tools can also support emerging bilingual students who were historically overlooked and underrepresented in STEM education. We anticipate the sponsorship of the STEM Institute to continue into the foreseeable future as we blend the best elements of our face-to-face and virtual workshops of past years into workshops that provide more diverse, equitable, and inclusive learning strategies. At the time of this writing, the Schulze Foundation has committed their support until 2023 with renewals available for future years.

\section{AUTHOR INFORMATION Corresponding Author}

Jessica Phillips Marcolini. jpmarcolini@fgcu.edu

\section{Author Contributions}

The manuscript was written through contributions of all authors. All authors have given approval to the final version of the manuscript.

\section{ACKNOWLEDGMENTS}

The authors would like to acknowledge Florida Gulf Coast University's Whitaker Center for STEM Education and the two former Directors (Laura Frost and Brian Johnson) for assisting in the administration of the workshop.

\section{FUNDING SOURCE}

Funding for the STEM Institute workshop is provided by the Richard M. Schulze Family Foundation. 


\section{ABBREVIATIONS}

FAST: Florida Association of Science Teachers; FGCU: Florida Gulf Coast University; ISIS: Inquiry Science Implementation Scale; SES: Socioeconomic Status; STEBI: Science Teaching Efficacy Belief Instrument

\section{REFERENCES}

Banks, A. J. (2004). Multicultural education: Historical development, dimensions, and practice. In J. A. Banks and C. A. McGee Banks (Eds.), Handbook of research on multicultural education. (pp.3-28). San Francisco: Jossey-Bass.

Batt, E. (2008). Teacher's perceptions of ELL education: Potential solutions to overcome the greatest challenges. Multicultural Education, 15(3), 39-43.

Beauchamp, L., Klassen, R., Parsons, J., Durksen, T., and Taylor, L. (2014). Exploring the development of teacher efficacy through professional learning experiences. Alberta Ministry of Education.

Bleicher, R. E. (2004). Revisiting the STEBI-B: Measuring self-efficacy in pre-service elementary teachers. School Science and Mathematics, 104(8), 383-391.

Bodur, Y. (2012). Impact of course and fieldwork on multicultural beliefs and attitudes. The Educational Forum, 76(1), 4156.

Brandon, P. R., Young, D. B., Pottenger, F. M., and Taum, A. K. H. (2009). The inquiry science implementation scale: Development and applications. International Journal of Science and Mathematics Education,7(6), 1135-1147.

Bursal, M., and Paznokas, L. (2006). Mathematics anxiety and pre-service elementary teachers' confidence to teach mathematics and science. School Science and Mathematics, 106(4), 173-179.

Bybee, R. (2009). The BSCS 5E Instructional Model and 21st Century Skills. Retrieved from https://sites.nationalacademies.org/cs/groups/dbassesite/documents/webpage/ dbasse_073327.pdf

Byun, S. Y., Meece, J. L., and Irvin, M. J. (2012). Rural-nonrural disparities in postsecondary educational attainment revisited. American Educational Research Journal, 49(3), 412437.

Conderman, G., and Woods, C. S. (2008). Science instruction: An endangered species, Kappa Delta Pi Record, 44(2), 76-81.

Cooper, S. J., Frost, L., and Osterman, A. (2014). K-12 STEM summer institute for teachers. Retrieved from https:// www.ssma.org/assets/Proceedings/SSMA-2014-Proceedings.FINALweb.pdf

CPALMS (2019). Retrieved from https://www.cpalms.org/Public/
Crawford, C., Obenland, C., and Nichol, C. (2021). An analysis of the effect of long-term professional development on teacher engineering self-efficacy and its impact on classroom instruction. Journal of STEM Outreach, 4(1), 1-10.

Darling-Hammond, L., Zielezinski, M. B., and Goldman, S. (2014). Using technology to support at-risk students' learning. Washington, DC: Alliance for Excellent Education.

Darling-Hammond, L., Hyler, M. E., and Gardner, M. (2017). Effective teacher professional development. Learning Policy Institute.

Darling-Hammond, L., Wei, R. C., Andree, A., Richardson, N., and Orphanos, S. (2009). Professional learning in the learning profession. Washington, DC: National Staff Development Council

Dennick, R. (2013). Analyzing multi-cultural and anti-racist science education. In S. Amos, and R. Boohan (Eds.), Teaching science in secondary schools: A reader (pp. 102-112). Routledge.

Edwards, S. (2011). Developing diversity dispositions for white culturally responsive teachers. Action in Teacher Education, 33(5-6), 493-508.

Eib, B. J., and Miller, P. (2006). Faculty development as community building - An approach to professional development that supports communities of practice for online teaching. The International Review of Research in Open and Distributed Learning, 7(2).

Flores, B. and Smith, H. (2008). Teachers' characteristics and attitudinal beliefs about linguistic and cultural diversity. Bilingual Research Journal, 31(1-2), 323-358.

Florida Department of Education (2019). Critical Teacher Shortage Areas Florida Public Schools. Retrieved from http:// www.fldoe.org/core/fileparse.php/7584/urlt/CTSA1920. pdf

Florida Department of Education (2020). Lunch Status. Retrieved from http://www.fldoe.org/accountability/data-sys/edu-info-accountability-services/pk-12-public-school-datapubs-reports/students.stml

Florida Gulf Coast University Digital Repository. (2021, July). Whitaker Center publication. http://fgcu.digital.flvc. org/islandora/search/?type $=$ edismax \& collection $=$ fg cu\%3Awhitakercenter

Gay, G. (2010). Acting on beliefs in teacher education for cultural diversity. Journal of Teacher Education, 61(1-2), 143-152.

Hodson, D. (1999). Critical multiculturalism in science and technology education. In S. May (Ed.), Critical multiculturalism: Rethinking multicultural and antiracist education (pp. 216-244). London, England: Routledge.

Housing and Urban Development Exchange (2021) Promise Zone Designations. Retrieved from https:/www.hudexchange. info/programs/promise-zones/promise-zones-overview/ 
Krim, J. S., Cote, L. E., Schwartz, R. S., Stone, E. M., Cleeves, J. J., Barry, K. J., Burgess, W., Buxner, S. R., Gerton, J. M., Horvath, L. Keller, J. M., Lee. S. C., Locke, S. M., and Rebar, B. M. (2019). Models and impacts of science research experiences: A review of the literature of CUREs, UREs, and TREs. Life Science Education, 18(4).

Lehrer, R., and Schauble, L. (2006). Cultivating model-based reasoning in science education. Cambridge University Press.

Ma, Y., and Liu, Y. (2017). Entry and degree attainment in STEM: The intersection of gender and race/ethnicity. Social Sciences, 6(3), 89.

Matherson, L., and Windle, T. M. (2017). What do teachers want from their professional development? Four emerging themes. Delta Kappa Gamma Bulletin, 83(3), 28.

Nadelson, L. S., Seifert, A., Moll, A. J., and Coats, B. (2012). i-STEM summer institute: An integrated approach to teacher professional development in STEM. Journal of STEM Education: Innovations and Research, 13(2), 69-83.

Nasser, H.E. and Overberg, P. (2012, May 23). Census continues to undercount Blacks, Hispanics and kids. Retrieved from http://usatoday30.usatoday.com/news/nation/story/2012-05-22/census-hispanic-black/55140150/1

National Research Council (2007). Taking Science to School: Learning and Teaching Science in Grades K-8, Washington, DC: National Academy Press.

National Research Council (2011). Successful K-12 STEM education: Identifying effective approaches in science, technology, engineering, and mathematics. Washington, DC: National Academy Press.

Nutta, J., Mokhtari, K. and Strebel, C. (2012). Preparing every teacher to reach English learners: A practical guide for teacher educators. Harvard Education Press.

Oliver, J. S., and Hodges, G. W. (2014). Rural science education. In N. G. Lederman and S, K, Abell (Eds.), Handbook on Research on Science Education (pp. 266-283). Routledge Handbooks Online.

Provasnik, S., KewalRamani, A., Coleman, M. M., Gilbertson, L., Herring, W., and Xie, Q. (2007). Status of education in rural America. US Department of Education, National Center for Education Statistics, Institute of Education Sciences.

Riggs, I. M. (1988). The development of an elementary teachers' science teaching efficacy belief instrument (Doctoral dissertation). Kansas State University, Kansas, US.

Riggs, I., and Enochs, L. (1990). Toward the Development of an Elementary Teacher's Science Teaching Efficacy Belief Instrument. Science Education 74(6): 625-637.

Schafft, K. A., Alter, T. R., and Bridger, J. C. (2006). Bringing the community along: A case study of a school district's information technology rural development initiative. Journal of Research in Rural Education, 21(8), 1-10.
Silverman, R., and Hines, S. (2009). The effects of multimedia-enhanced instruction on the vocabulary of English-language learners and non-English-language learners in pre-kindergarten through second grade. Journal of Educational Psychology, 101(2), 305-3014.

Tschannen-Moran, M., Woolfolk Hoy, A., and Hoy, W. K. (1998) Teacher efficacy: Its meaning and measure. Review of Educational Research, 68(2), 20

Ukopokodu, O. (2011). Developing teachers' culture competence: One teacher educator's practice of unpacking student culturelessness. Action in Teacher Education, 33(5-6), 432454.

Vasquez, J., Sneider, C., and Comer, M. (2013). STEM lesson essentials, grades 3- 8: Integrating Science, Technology, Engineering, And Mathematics. Portsmouth, NH: Heinemann. Retrieved from http://www.heinemann.com/shared/ onlineresources/E04358/stemsamplechapter.pdf

Wenger, E. (2010). Communities of practice and social learning systems: the career of a concept. In C. Blackmore (Ed.), Social Learning Systems and Communities of Practice (pp. 179-198). Springer, London.

Wiggins, G., and McTighe, J. (1998). Understanding by design. Alexandria, VA: Association for Supervision and Curriculum Development.

Wilson, S. (2011). Effective STEM teacher preparation, induction, and professional development. Paper presented at the National Research Council Workshop on Successful STEM Education in K-12 Schools. Retrieved from http://sites.nationalacademies.org/dbasse/bose/dbasse 071087 